\title{
Constructivist Pedagogic Method Used in the Teaching of Human Anatomy
}

\author{
Método Constructivista Pedagógico Usado en la Enseñanza de la Anatomía Humana \\ "Mariana Flavia Mota; "Fabiana Ribeiro da Mata \& **Tales Alexandre Aversi-Ferreira
}

MOTA, M. F.; MATA, F. R. \& AVERSI-FERREIRA, T. A. Constructivist pedagogic method used in the teaching of human anatomy. Int. J. Morphol., 28(2):369-374, 2010.

SUMMARY: This study aimed to demonstrate that the learning in the discipline of human anatomy is more significant with the use of a constructivist pedagogic methodology in relation to traditional teaching, enabling students to the effective construction of knowledge. Practical lessons in human anatomy were given for students from first semesters of the Physical Education course, Federal University of Goiás, using a constructivist methodology for the teaching of the Digestive System. The students were divided into 5 groups containing 7 students each. Each group used the class guide prepared by teachers, containing the structures to be studied, in addition to textbook and Anatomy Atlas. The data were analyzed using the Graph pad prism software (version 5.00) and submitted to testing for comparison of means ( $t$ test at $5 \%$ probability). The use of the new constructivist pedagogic methodology facilitated the learning for most students $(80.65 \%)$ and $61.29 \%$ rated their learning as good. There was an increase in the time of permanence in the classroom, in the participation in practical classes and in the consultation to bibliographies recommended. About $64.51 \%$ of students felt that the practical lessons contributed to a better learning and most students $(90.31 \%)$ considered their participation in the practical classes more active. In conclusion, the use of constructivist pedagogic methodology in teaching human anatomy facilitated the learning by the students involved in this work, making it more significant when compared to the traditional methodology.

KEY WORDS: Human anatomy; Teaching-learning; Anatomy teaching; Constructivist bases.

\section{INTRODUCTION}

Anatomy is one of the oldest basic medical sciences. The first anatomical descriptions were recorded on papyrus between 3000 and $5000 \mathrm{BC}$, being formally studied for the first time in Egypt (about 500 BC). It began to be taught in Greece by Hippocrates (460 - 377 BC), which is considered the father of medicine and founder of the science of anatomy (Moore \& Dalley, 2007).

The teaching of anatomy has been administered in the same way since the times of its initiation as a science (Aversi-Ferreira, 2009), although not all students achieve significant learning. However, some authors have introduced alternative methodologies well accepted by students and thus, learning became more effective (Aversi-Ferreira et al., 2008; Freitas et al., 2008).

Tavares \& Alarcão (2001) consider that in the traditional paradigm of education, higher education teachers teach, transmit and explain to students the regular and available science. The emphasis is on the teacher, knowledge and its acquisition. According to Luckesi (1999), the reception of knowledge is little for the student to develop skills and habits, being required exercising this knowledge. Moreover, in the post-modern paradigm, the student must be the builder of his knowledge, and less teaching and more learning is recommended. Brzezinski (2005) considers that within this new process, it is no longer possible to separate teaching from learning, and there is one only if there is another. Thus, the teaching of anatomy through the practical study of parts provides an important mechanism for learning.

Learning, according to the cognitive-constructivist theories, is the personal construction resulting from an experiential process, particular to each person, which is translated as a relatively stable behavior modification. It is a dynamic process, a personal experience leading to the

\footnotetext{
* Departament of Morphology (DMORF), Institute of Biological Sciences (ICB), Federal University of Goias (UFG), Brazil.

** Neurosciences and Primates Behaviour Laboratory (NECOP), Department of Nurse (DE), Campus of Catalão, Federal University of Goiás, Goiânia GO, Brazil.
} 
construction of knowledge. It requires the acquisition of knowledge and the ability to process it and store it in memory (Almeida \& Tavares, 1998; Boruchovitch \& Bzuneck, 2004; Valle, 2006). Exercising knowledge requires more active methods (Luckesi). Only in this way, learning can be effective. Therefore, it is different from the simple acquisition of information afforded by the traditional paradigm.

Thus, learning occurs more effectively when the student experiences the content/objects of knowledge using various channels of reception and processing of information (auditory, visual, tactile, kinesthetic, and others), because learning occurs from the interaction between subject and environment, being facilitated when this interaction occurs through various channels and when new information has personal meaning, i.e., there is motivation to learn (Valle). In order for teachers and students to be protagonist of the teaching-learning process, it is up to the teacher the selection of the teaching procedures most suitable for the construction of knowledge by students.

This study aimed to verify, through questionnaires, if the learning the discipline of Human Anatomy achieved greater receptivity by students when compared with traditional and constructivist methodologies in the classroom.

\section{MATERIAL AND METHOD}

Practical lessons in human anatomy were given for students from first semesters of Physical Education course, Federal University of Goiás, using a constructivist methodology for the teaching of the Digestive System. The other systems were studied with teacher indicating the names of the parts to a group of students around the table. The students were divided into 5 groups containing 7 members each. The anatomical parts for the practical study of the digestive system were distributed in 5 tables in the laboratory. Each group chose a table and received the guide, elaborated by the teachers, containing the structures to be studied, as well as a textbook and Atlas of Anatomy. Students carried out the study as follows:

1. Identification of the structures to be studied in the guide. 2. Study in the textbook and / or atlas of anatomy on the structure selected for the formation of theoretical knowledge. 3. Questioning teachers and monitors whenever doubts emerge.

The groups exchanged table after the end of the study of all parts, therefore, at the end of practical classes, the students completed the study of the entire content of the digestive system. A questionnaire (Table I) containing ten objective questions, including a space for comments and suggestions was applied to all students to evaluate the following: learning, participation, interest, student satisfaction with the use of the constructivist pedagogic methodology and comparison with the traditional method in lecture and demonstrative classes.

The data were analyzed using the Graph pad prism software (version 5.00 for Windows XP, Graph Pad Software, San Diego, California) and submitted to test for comparison of means ("t" test for $\mathrm{p}<0.05$ ).

\section{RESULTS}

The questionnaire was responded by 34 students (Table I). After analyzing the questionnaire, it was found that $61.29 \%$ of students rated their learning as good and $32.26 \%$ as excellent, and $6.45 \%$ as regular and no students responded as poor (Fig. 1). It was responded that using the new constructivist pedagogic methodology helped to facilitate learning for most students (80.65\%), and 19.35\% considered only a slight improvement in learning.

With regard to permanence in the classroom during the practical sessions, with the traditional methodology, $35.48 \%$ assessed as good and $32.26 \%$ as regular. Using the constructivist pedagogic methodology, the permanence in the classroom in the practical classes was evaluated by $48.39 \%$ as excellent and $38.71 \%$ as good. Participation in practical sessions with the traditional methodology was evaluated as $38.71 \%$ as good and $35.48 \%$ as regular. Using the methodology with constructivist bases, $45.16 \%$ of students assessed their participation as excellent and $48.39 \%$ as good. The frequent query to recommended bibliography increased from $6.45 \%$ to $38.71 \%$ with the change of methodology and $64.51 \%$ of students responded that the practical classes contributed to higher learning (Fig. 2). Most students $(90.31 \%)$ considered their participation in practical classes as more active (Fig. 3) with the use of the constructivist pedagogic methodology.

In the comparative analysis between methods, there were significant differences at $\mathrm{p}<0.05$.

In the room for suggestions and comments, students reported to have enjoyed the methodology used in the classroom. Some sayings were: "The new methodology encourages participation and learning, forcing us to seek and learn," "I wish the teacher continued using this methodology," "With the change in methodology, my participation in practical classes was higher, as it required 
MOTA, M. F.; MATA, F. R. \& AVERSI-FERREIRA, T. A. Constructivist pedagogic method used in the teaching of human anatomy. Int. J. Morphol., 28(2):369-374, 2010.

Table I. Questionnaire assessing methodologies responded by Physical Education students - Federal University of Goiás.

\begin{tabular}{|c|c|c|}
\hline \multirow[t]{4}{*}{ 1- How do you rate your learning on the digestive system? } & a) Excelent & $32.26 \%$ \\
\hline & b) Good & $61.29 \%$ \\
\hline & c) Regular & $6.45 \%$ \\
\hline & d) Poor & 0.0 \\
\hline \multirow[t]{3}{*}{ 2- Does the new methodology used contribuye to a better learning? } & a) Yes & $80.65 \%$ \\
\hline & b) Reasonably & $19.35 \%$ \\
\hline & c) No & 0.0 \\
\hline \multirow{4}{*}{$\begin{array}{l}\text { 3- How do you rate your permanece in classes in the previous } \\
\text { methodology? }\end{array}$} & a) Excelent & $29.03 \%$ \\
\hline & b) Good & $35.48 \%$ \\
\hline & c) Regular & $32.26 \%$ \\
\hline & d) Poor & $3.23 \%$ \\
\hline \multirow{4}{*}{$\begin{array}{l}\text { 4- How do you rate your permanence in classroom Turing practical } \\
\text { classes with the methodology used practical classes? }\end{array}$} & a) Excelent & $48.39 \%$ \\
\hline & b) Good & $38.71 \%$ \\
\hline & c) Regular & $12.9 \%$ \\
\hline & d) Poor & 0.0 \\
\hline \multirow{4}{*}{$\begin{array}{l}\text { 5- Hoe do you rate your participation Turing practical classes previous } \\
\text { to digestive system? }\end{array}$} & a) Excelent & $22.58 \%$ \\
\hline & b) Good & $38.71 \%$ \\
\hline & c) Regular & $35.48 \%$ \\
\hline & d) Poor & $3.23 \%$ \\
\hline \multirow{4}{*}{$\begin{array}{l}\text { 6- How do you rate your participation Turing practical classes of the } \\
\text { digestive system? }\end{array}$} & a) Excelent & $45.16 \%$ \\
\hline & b) Good & $48.39 \%$ \\
\hline & c) Regular & $6.45 \%$ \\
\hline & d) Poor & 0.0 \\
\hline \multirow{3}{*}{$\begin{array}{l}\text { 7- Did you participate more actively of practical classes of the digestive } \\
\text { system? }\end{array}$} & a) Yes & $90.31 \%$ \\
\hline & b) Reasonably & $6.45 \%$ \\
\hline & c) No & $3.23 \%$ \\
\hline \multirow{4}{*}{$\begin{array}{l}8 \text { - In previous classes, did you search for recommended bibliography } \\
\text { Turing practical classes? }\end{array}$} & a) Always & $6.45 \%$ \\
\hline & b) Frecuently & $25.80 \%$ \\
\hline & c) Regular & $48.39 \%$ \\
\hline & d) Never & $19.35 \%$ \\
\hline \multirow{4}{*}{$\begin{array}{l}\text { 9- During practical classes, you searched for recommended } \\
\text { bibliography? }\end{array}$} & a) Always & $38.71 \%$ \\
\hline & b) Frecuently & $38.71 \%$ \\
\hline & c) Regular & $22.58 \%$ \\
\hline & d) Never & 0.0 \\
\hline \multirow{3}{*}{$\begin{array}{l}\text { 10- Did the practical classes contribuye to a better learning of the } \\
\text { digestive system? }\end{array}$} & a) Yes & $96.77 \%$ \\
\hline & b) Reasonably & $3.23 \%$ \\
\hline & c) No & 0.0 \\
\hline
\end{tabular}

more my attention, "" This methodology does not require extra time to study because we have studied learning", " I really enjoyed the new methodology, I felt more active in classroom, I learned more and got interested because it is myself to look for structures", " The new method is excellent for learning because the student is more interested and engaged and therefore learns more", "My suggestion is to continue with this methodology, because students can control more of what they learn or not, and contributes to group work". 

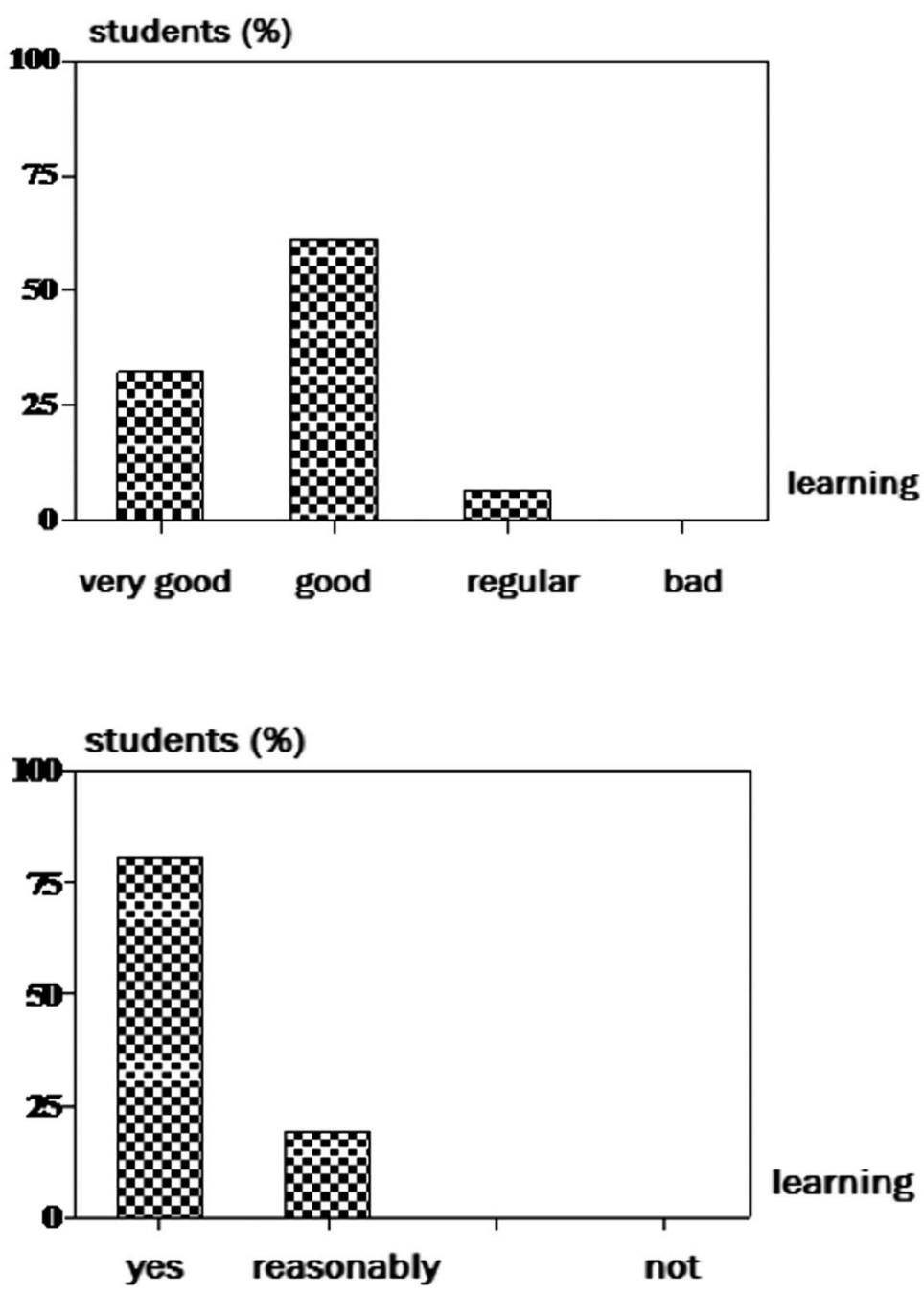

Fig. 1. Assessment of the learning on the digestive system by students from the first semester of the Physical Education course, Federal University of Goiás through the use of the constructivist pedagogic methodology.

Fig. 2. Contribution from practical classes for further learning of the digestive system through the use of the constructivist pedagogic methodology.

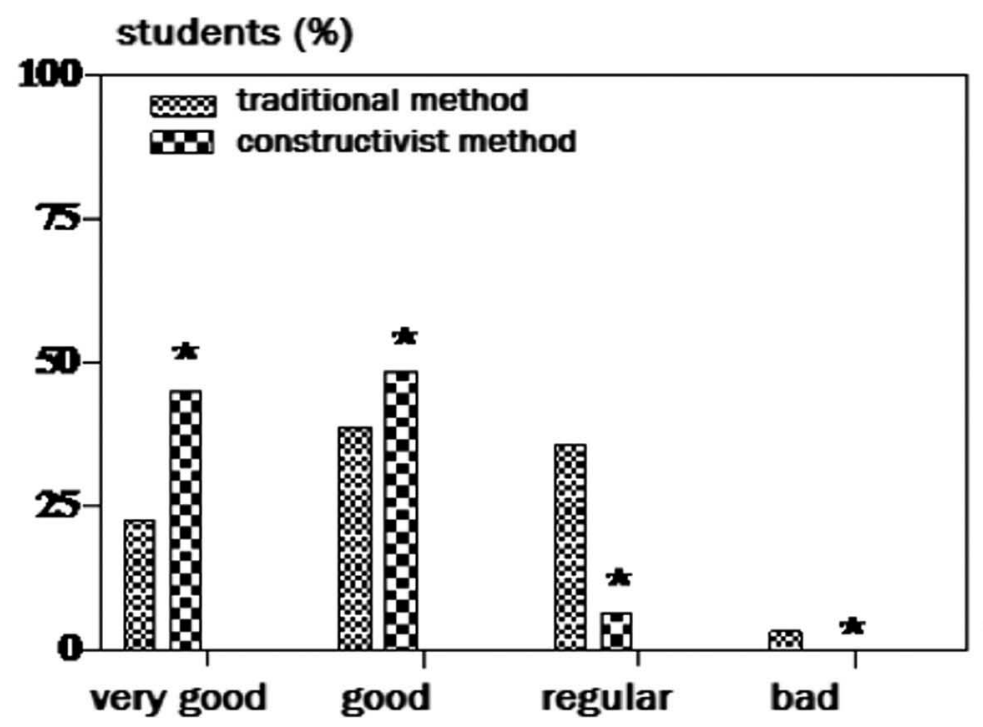

Fig. 3. Comparison between methodologies used in the study (*significant for $\mathrm{p}<0.05$ ). 
Three students suggested more disperse groups of students to minimize the noise, one student suggested that the teacher should do a review of students after a study and one student said that the previous methodology, the lecture one, gives students a broader knowledge, since the participatory methodology, although good, does not give the opportunity for the teacher to convey their experiences to students.

\section{DISCUSSION}

The constructivist pedagogic methodology facilitated learning according to responses from most students because it allowed a more active and participatory learning and each student could learn their own way and time because, according to Almeida \& Tavares (1998), even students with relatively the same cognitive ability may have different cognitive styles.

The use of active methodologies by the teacher facilitates the construction of knowledge by the student, making him not a mere receiver of information. Active methodologies, with constructivist bases, allow students to build their knowledge mediated by the teacher. According to Nóvoa (2002), the success of the teacher depends on the active cooperation from the student.

Thus, meaningful learning occurs when the student participates as active subject of the teaching - learning process in a partnership with the teacher and peers in the classroom, seeking for information, giving meaning to them, comparing them with his intellectual world, integrating theory and practice and finding solutions to problems raised (Musetto). In this work, the students showed that learning was actually more significant when they were more active in the process.

In research conducted by Furlani (2004), college students stressed the importance of classes and teacher mediation to their training. They face the challenges with motivation and enthusiasm, being asked to continuous actions and elaboration of own productions under the guidance of teachers. As demonstrated in this study that the use of constructivist pedagogic methodology allowed an increase in participation and permanence of the students in the classroom during class practice.

This improves enhancers (consequences that increase the frequency of the previous behavior), because in a way, when the student finds out a structure, he has the feeling of accomplishment and increased self-esteem because he is the author of his learning, obtaining a powerful reinforcer, which is the immediate success of his actions associated with a recent accomplishment.
The student who comes to university, comes from an educational system aimed at passivity, information receiving, storing, individualism, interest on the grade and that believes that a good teacher is the one that explains the contents well, and holds students' attention (Pimenta \& Anastasiou, 2002); however, students felt more involved in the teaching - learning process when acting directly on the acquisition of knowledge. This feeling tends to turn in greater commitment to their professional training and development of a skill much valued in the labor market, to work as a team.

Of course, this commitment can and should make the student more demanding with the teacher because the teacher is no longer the only source of knowledge during classroom because the students receive more theoretical and methodological bases to question the teacher. This is beneficial to encourage a better training of teachers and at the same time, to make the student learn to learn, alone and in groups.

Literature, teaching practice and the questionnaire made clear the importance of the active student participation in the teaching - learning process and the need for the construction of knowledge by students so that learning is really significant, reflecting in the formation of critical and reflexive individuals and qualified professionals.

The students felt more motivated, interested and were more involved in classes. The teacher's role became nobler because it is no longer a mere transmitter of knowledge, which students could acquire through any other media (books, internet and others) and became a mediator, a partner of the students in the search for knowledge.

In short, the use of constructivist pedagogic methodologies in the teaching of human anatomy facilitated the learning by the students involved in this work, making it more significant than the traditional methodology.

MOTA, M. F.; MATA, F. R. \& AVERSI-FERREIRA, T.A. Metodo construtivista pedagogico usada en la enseñanza de la anatomia humana. Int. J. Morphol., 28(2):369-374, 2010.

RESUMEN: El objetivo de este estudio fue demostrar que el aprendizaje en la disciplina de anatomía humana es más significativa con el uso de una metodología pedagógica constructivista, en relación a la enseñanza tradicional, capacitando así a los alumnos en una construcción efectiva de conocimiento. Se impartieron lecciones prácticas en Anatomía Humana a los alumnos de primer semestre del curso de Educación Física, Universidad Federal de Goiás, usando una metodología constructivista para la enseñanza del Sistema Digestivo. Los alumnos fueron divididos en 5 grupos con 7 alumnos por grupo. Cada grupo utilizó la guía de clase preparada por los profesores, las que contenían las estructuras a estudiar, además del texto y de un Atlas de Anatomía. La información 
fue analizada usando el software Graph pad prism (versión 5.00) y sometido a prueba para la comparación de los medios ( $\mathrm{t}$ test al $5 \%$ de probabilidad). El uso de la nueva metodología pedagógica constructivista, facilitó el aprendizaje para la mayoría de los estudiantes $(80.65 \%)$ y el $61.29 \%$ calificaron su aprendizaje como bueno. Aumentó el tiempo de permanencia en la sala de clases, en la participación de clases prácticas y en la consulta de bibliografías recomendadas. Aproximadamente un $64.51 \%$ de los alumnos indicaron que la lección práctica contribuyó a un mejor aprendizaje, y la mayoría de los alumnos $(90.31 \%)$ consideraron que su participación en las clases prácticas fue más activa. En conclusión el uso de la metodología pedagógica constructivista en la docencia de Anatomía Humana, facilitó el aprendizaje de los alumnos involucrados en ese trabajo, haciéndolo más significativo al ser comparado con la metodología tradicional.

PALABRASCLAVE: Anatomía humana; Enseñanza y Aprendizaje; Enseñanza de La anatomia; Bases constructivista.

\section{REFERENCES}

Almeida, L. S. \& Tavares, J. Conhecer, aprender, avaliar. Porto, Porto editora, 1998.

Aversi-Ferreira, T. A.; Monteiro, C. A.; Maia, F. A.; Guimarães, A. P. R. \& Cruz, M. A. Neurophysiology study associated with three-dimensional models constructed during the learning. Biosci. J., Uberlândia, 24(1):98-103, 2008.

Aversi-Ferreira, T. A. Comparative anatomical description of the forearm and hand arteries of Cebus libidinosus. Int. J. Morphol., 27(1):219-226, 2009.

Boruchovitch, E. \& Bzuneck, J. A. Aprendizagem por processamento da informação: uma visão construtivista. In: Aprendizagem: processos psicológicos e o contexto social na escola. Petrópolis-RJ, Vozes, 2004.

Brzezinsk, I. Qualidade na graduação. Educativa, 8(2):321$38,2005$.

Freitas, L. A. M.; Barroso, H. F. D.; Rodrigues, H. G.; AversiFerreira, T. A. Construction of embryonic models with recycled material for didactic using. Biosci. J., Uberlândia, 24(1):91-7, 2008.

Furlani, L. M. T. A parceria e a aproximação na relação professor-aluno na universidade. In: Almeida, L. R.; Placco, V. M. N. S. As relações interpessoais na formação de professores. São Paulo-SP, Loyola, 2004.
Luckesi, C. C. Procedimentos de ensino. In: Filosofia da educação. São Paulo-SP, Cortez, 1999.

Masetto, M. T. Docente de ensino superior atuando num processo de ensino ou de aprendizagem. In: Competência Pedagógica do professor universitário. São Paulo-SP, Summus, 2003.

Moore, K. L. \& Dalley, A. F. Anatomia orientada para a clínica, 5a Ed. Rio de Janeiro-RJ, Guanabara Koogan, 2007.

Nóvoa, A. Dilemas da profissão docente. In: Formação de professores e trabalho pedagógico. Lisboa, EDUCA, 2002.

Pimenta, S. G. \& Anastasiou, L. G. Docência e ensino: ensinar a quem? In: Docência no ensino superior. São Paulo-SP, Cortez, 2002.

Tavares, J. \& Alarcão, I. Paradigmas de formação e investigação no ensino superior para o terceiro milênio. In: Escola reflexiva e nova racionalidade. Porto AlegreRS, Artmed, 2001.

Valle, L. E. L. R. Neuropsicologia e psicopedagogia: desenvolvimento integrado de competências essenciais para a aprendizagem. In: Maluf, M. I. Aprendizagem: tramas do conhecimento, do saber e da subjetividade. Petrópolis-RJ, Vozes, 2006.

Correspondence to:

Dr. Tales Alexandre Aversi-Ferreira.

Universidade Federal de Goiás - Campus Catalão

Setor Universitário, Catalão/GO

Departamento de Enfermagem

Avenida Dr. Lamartine Pinto de Avelar, 1120.

Goiás

BRASIL

Phone: +55 64 3441-1500

Fax: +55 64 3441-1515.

Email: aversiferreira@hotmail.com

Received: 25-10-2009

Accepted: 23-04-2010 